\title{
Morphology and molecular characterization of Demidospermus spirophallus n. sp., D. prolixus n. sp. (Monogenea: Dactylogyridae) and a redescription of D. anus in siluriform catfish from Brazil
}

\author{
L. Franceschini ${ }^{1 *}$, A.C. Zago $^{1}$, M.I. Müller ${ }^{1}$, C.J. Francisco ${ }^{1}$, \\ R.M. Takemoto ${ }^{2}$ and R.J. da Silva ${ }^{1}$
}

${ }^{1}$ São Paulo State University (Unesp), Institute of Biosciences, Botucatu, Brazil, CEP 18618-689: ${ }^{2}$ State University of Maringá (UEM), Limnology, Ichthyology and Aquaculture Research Center (Nupélia), Maringá, Brazil, CEP 87020-900

(Received 29 September 2016; Accepted 26 February 2017; First published online 6 April 2017)

\begin{abstract}
The present study describes Demidospermus spirophallus n. sp. and Demidospermus prolixus n. sp. (Monogenea, Dactylogyridae) from the siluriform catfish Loricaria prolixa Isbrücker \& Nijssen, 1978 (Siluriformes, Loricariidae) from the state of São Paulo, Brazil, supported by morphological and molecular data. In addition, notes on the circumscription of the genus with a redescription of Demisdospermus anus are presented. Demidospermus spirophallus $\mathrm{n}$. sp. differed from other congeners mainly because of the morphology of the male copulatory organ (MCO), which exhibited 21/2 counterclockwise rings, a tubular accessory piece with one bifurcated end and a weakly sclerotized vagina with sinistral opening. Demidospermus prolixus n. sp. presents a counterclockwise-coiled MCO with $1 \frac{1}{2}$ rings, an ovate base, a non-articulated groove-like accessory piece serving as an MCO guide, two different hook shapes, inconspicuous tegumental annulations, a non-sclerotized vagina with sinistral opening and the absence of eyes or accessory eyespots. The present study provides, for the first time, molecular characterization data using the partial ribosomal gene (28S) of two new species of Demidospermus from Brazil (D. spirophallus n. sp. and D. prolixus n. sp.), and Demidospermus anus from Loricariichthys platymetopon Isbrücker \& Nijssen, 1979 collected in the Upper Paraná River floodplain, Brazil. Additionally, a revision of the species composition of this genus and others that occur in catfish is proposed to elucidate problems with their circumscription. The Brazilian species of Demidospermus clustered together as sister taxa among Neotropical dactylogyrids from siluriforms. The morphological characterization of D. spirophallus $\mathrm{n}$. $\mathrm{sp}$. and D. prolixus n. sp., and the molecular data of the three species in the present study will extend knowledge about this monogenean genus from the Neotropical region, and provide new information for future phylogeny studies.
\end{abstract}


3000 valid living species distributed in freshwater, brackish and marine environments in every continent of the world (Nelson, 2006; Sullivan et al., 2006; Eschmeyer et al., 2016). Most of these species are widely distributed in Neotropical regions (around $50 \%$ of the total number of species), although a large minority (about 72 species) are endemic and have restricted geographic ranges, being known only from the original site and basins in which they were discovered (Burguess, 1989; Eschmeyer et al., 2016; Froese \& Pauly, 2016). Loricariidae is one of the most diverse families of this order in numbers of genera and species. This family includes seven subfamilies (Chiachio et al., 2008) and 900 valid species, making this taxon the second most species-rich family of Neotropical freshwater fishes after Characidae (Roxo et al., 2014). Many species are of considerable economic importance, being sold for use in aquariums or for human consumption, mainly by riverside populations.

In general, loricariids present high intraspecific phenotypic plasticity, resulting in a great variability of shapes and colour throughout their ontogenetic development. Our limited knowledge of their biological characteristics, together with the biogeographic patterns of distribution and high morphological variability of the loricariids, make studies on the group difficult (Reis et al., 1990; Weber, 2003; Armbruster, 2004). Catfish are suitable hosts for a rich and diverse fauna of gill monogeneans, representing an interesting model for phylogenetic studies of monogeneans from the Neotropical region (MendozaPalmero et al., 2012).

Monogeneans represent a diverse group of fish parasites, in terms of number of species, morphology and ecology (Poulin, 2002; Thatcher, 2006). These parasites are known to be highly host specific, parasitizing only one host species or a narrow group of closely related fishes (Thatcher, 2006). The host specificity shown by most monogeneans makes it easier to relate the ecological characteristics of the hosts and the diversity of their monogenean parasites, and to control the phylogenetic history of their associations (Poulin, 2002). Dactylogyridae is one of the most important and largest families among these parasites, occurring in different species of fishes from continental waters of South America (Thatcher, 2006). Approximately 379 nominal species belonging to 31 genera have been described in siluriform fishes, with an increasing number of new descriptions in recent years (Mendoza-Palmero et al., 2012, 2015; Cohen et al., 2013). Most of the descriptions are based on morphological data, and do not provide the molecular characterization of the species described. Molecular techniques have been used to support taxonomic and morphological descriptions of monogeneans, and provide ways of performing phylogenetic analysis based on different markers (e.g. 18S, internal transcribed spacer (ITS) and $28 \mathrm{~S}$ rDNA regions of the rDNA gene, and cytochrome $c$ oxidase (COI) and $16 \mathrm{~S}$ mitochondrial genes) (Plaisance et al., 2005; Simková et al., 2006; Wu et al., 2006, 2007, 2008; Fehlauer-Ale \& Littlewood, 2011; Hahn et al., 2011; Gilmore et al., 2012; Sarabeev \& Desdevises, 2014; Mendoza-Palmero et al., 2015), and a means of elucidating the relationship between parasite species, their hosts and the relationship between them (Poulin, 2002; Braga et al., 2014).
Demidospermus was erected to include Demidospermus anus Suriano, 1983 as the type species, collected from the gills of Loricariichthys anus (Valenciennes, 1835) (= Loricaria anus) from Argentina. Currently, Demidospermus represents one of the most specious genera among dactylogyrids of freshwater siluriforms (Mendoza-Palmero et al., 2012), with 29 valid species (including two new species described here) reported in a great variety of catfish species from South America (Mendoza-Palmero et al., 2012). Mendoza-Palmero et al. (2015), in a study on the phylogeny of monogenean parasites on Neotropical catfishes, presented the first molecular data of Demidosmermus species (D. mortenthaleri Mendoza-Palmero, Scholz, Mendoza-Franco \& Kuchta, 2012 and two other undescribed species, Demidospermus sp. 11 and Demidospermus sp. 23), parasites of Brachyplatystoma juruense (Boulenger, 1898) and Brachyplatystoma vaillantii (Valenciennes, 1840) (Pimelodidae), respectively, from Iquitos, Peru. The results of their analyses reveal that dactylogyrids from Neotropical catfishes do not represent a monophyletic group, and suggest that the genus Demidospermus is not natural, requiring revision of the species composition and phylogeny.

The aim of the present study was to describe two new species of Demidospermus, supported by morphological and molecular data, both gill parasites of Loricaria prolixa Isbrücker \& Nijssen, 1978 from the Sapucaí-Mirim River, in the state of São Paulo, Brazil. Additionally, the molecular characterization of $D$. anus parasites of the gills of Loricariichthys platymetopon Isbrücker \& Nijssen, 1979, from the floodplain of the Upper Paraná River, Brazil, and their phylogenetic relationship with other parasites of siluriform fishes are presented.

\section{Materials and methods}

\section{Collection and examination of samples}

Fifty specimens of L. prolixa were collected between March 2012 and December 2013 in the reservoirs of three small hydroelectric power plants (SHPP) (ANEEL,

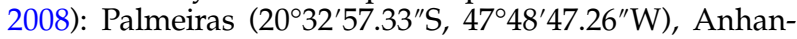
guera $\left(20^{\circ} 29^{\prime} 38.38^{\prime \prime} \mathrm{S}, 47^{\circ} 51^{\prime} 33.11^{\prime \prime} \mathrm{W}\right)$ and Retiro $\left(20^{\circ} 26^{\prime}\right.$ $\left.12.5^{\prime \prime} \mathrm{S}, 47^{\circ} 53^{\prime} 18.59^{\prime \prime} \mathrm{W}\right)$, all in the Sapucaí-Mirim River, near the municipalities of Guará and São Joaquim da Barra, in the state of São Paulo, Brazil. Additionally, five specimens of L. platymetopon were collected in June 2016 in the Upper Paraná River floodplain, near the municipality of Porto Rico, Brazil $\left(20^{\circ} 43^{\prime} \mathrm{S}, 53^{\circ} 10^{\prime} \mathrm{W}\right)$ during the sampling of the Long-Term Ecological Research Program (Pesquisas Ecológicas de Longa Duração - PELD) of the Ichthyology and Aquaculture Research Center (Nupélia) of the State University of Maringá.

Fish were collected from 17.00 to 07.00 hours using a nylon monofilament gill net. The fish specimens were stored individually in plastic bags and placed in a Styrofoam box with ice for immediate transportation to the laboratory where they were measured $(\mathrm{cm})$, weighed (g) and necropsied.

The gills were removed and analysed fresh or placed in vials containing hot water (about $60^{\circ} \mathrm{C}$ ). They were then shaken and absolute ethanol was added (Thatcher, 2006). The monogeneans were collected using a stereomicroscope and some specimens were mounted in Gray 
and Wess, Hoyer or GAP (glycerin and picric acid) medium to highlight the sclerotized structures, while others were stained with Gömöri's trichrome and mounted in Canada balsam for analysis of the internal organs (Kritsky et al., 1986). Measurements (in micrometres) are presented as the mean, followed by the range and number of specimens measured $(n)$ in parentheses.

Morphological and morphometrical analyses were performed using a computerized image analysis system with differential interference contrast (DIC) (Leica Application Suite, V3; Leica Microsystems, Wetzlar, Germany). The illustrations of the sclerotized structures were produced with the aid of a camera lucida mounted on a Leica DMLS microscope, with phase contrast optics.

Voucher specimens of the fish host were deposited in the Ichthyological Collection of the Limnology, Ichthyology and Aquaculture Research Center) (NUP) of the State University of Maringá, state of Paraná, Brazil (NUP 15002). The holotype and paratypes of the proposed new species were deposited in the Helminthological Collection of the Oswaldo Cruz Institute (CHIOC), Rio de Janeiro, Brazil, and voucher specimens were deposited in the zoological collection of the Amazonas National Research Institute, state of Amazonas, Brazil (INPA) and the Helminthological Collection of the Department of Parasitology, Institute of Biosciences, São Paulo State University - UNESP (CHIBB), in the municipality of Botucatu, São Paulo, Brazil.

Cohen \& Kohn (2008) reported the occurrence of $D$. anus parasitizing L. platymetopon from the Itaipu Reservoir, in the state of Paraná, Brazil, and lent their material mounted on permanent slides for the analysis of the present study. Four paratypes of Demidospermus paranaensis Ferrari-Hoeinghaus, Bellay, Takemoto \& Pavanelli, 2010 deposited at the Helminthological Collection of the Oswaldo Cruz Institute (CHIOC 37255) were also examined. The scientific names of the hosts follow Froese \& Pauly (2016).

\section{Molecular analysis}

To ensure that species separation was performed correctly and to confirm identification, each parasite specimen subjected to molecular analysis was mounted on a slide with glycerin and photographed. The same specimens were then used for molecular characterization. The total genomic DNA was extracted using the Qiagen Dneasy ${ }^{\circledR}$ Blood and Tissue Kit (Qiagen, California, USA), $30 \mu \mathrm{l}$ for each sample, according to the manufacturer's protocol. Conventional polymerase chain reaction (PCR) amplifications were performed in $25-\mu 1$ reaction mixes, containing 5 $\mu \mathrm{l}$ of DNA extract, $0.5 \mu \mathrm{l}$ of each PCR primer using Ready-to-Go PCR beads (Pure Taq ${ }^{\mathrm{TM}}$ Ready-to-Go ${ }^{\mathrm{TM}}$ beads, GE Healthcare, Chicago, USA), a solution consisting of the stabilizer bovine serum albumin (BSA), deoxynucleoside triphosphates (dNTP: dATP, dCTP, dGTP and dTTP), $\sim 2.5$ units of puReTaq DNA polymerase and reaction buffer. The beads were reconstituted to a final volume of $25 \mu \mathrm{l}$ and the concentration of each dNTP was $200 \mu \mathrm{m}$ in $10 \mathrm{~mm}$ Tris- $\mathrm{HCl}$ ( $\mathrm{pH} 9.0$ at room temperature), $50 \mathrm{~mm} \mathrm{KCl}$ and $1.5 \mathrm{mM} \mathrm{MgCl}_{2}$. The thermocycling profile employed was: initial denaturation of DNA at $94^{\circ} \mathrm{C}$ for $3 \mathrm{~min}$; followed by 34 cycles of amplification at $94^{\circ} \mathrm{C}$ for $30 \mathrm{~s}, 56^{\circ} \mathrm{C}$ for $30 \mathrm{~s}$ and $72^{\circ} \mathrm{C}$ for $1.5 \mathrm{~min}$; and a final extension at $72^{\circ} \mathrm{C}$ for $7 \mathrm{~min}$ (Mendoza-Palmero et al., 2015). The primers used for amplification and sequencing were partial 28S rDNA (large subunit, LSU) fragments U178 (5'-GCA CCC GCT GAA YTT AAG-3') and L1642 (5'-CCA GCG CCA TCC ATT TTC A-3') (Lockyer et al., 2003), and L1200R (5'-GCA TAG TTC ACC ATC TTT CGG-3') for sequencing (Littlewood et al., 2000).

PCR products were run on agarose gels using GelRed and loading buffer, and purified using the QIAquick PCR Purification Kit (Qiagen). Automated sequencing was performed directly on the purified PCR products from specimens using BigDye v.3.1 Terminator Cycle Sequencing Ready Reaction kit (Applied Biosystems, Foster City, California, USA) for cycle sequencing. Sequences were run on an Applied Biosystems ABI 3500 DNA genetic analyser.

\section{Phylogenetic analysis}

For phylogenetic analysis, contiguous sequences were edited in Sequencher ${ }^{\mathrm{TM}}$ v.5.2.4 (Gene Codes, Ann Arbor, Mitchigan, USA) and were subjected to BLAST analysis (http://blast.ncbi.nlm.nih.gov) to confirm identity sequences. Newly generated sequences of partial $28 \mathrm{~S}$ rDNA were aligned with related sequences obtained previously from dactylogyrids of catfishes retrieved from GenBank (table 1). Dictyocotyle coeliaca Nybelin, 1941 (AF348359) was used as an outgroup. The species, hosts and accession numbers used in this study are described in table 1.

Nucleic acid sequences were aligned using the Muscle program implemented in Geneious version 7.1.3 (Kearse et al., 2012). All analyses were performed using only positions that were unambiguously alignable across all taxa. The phylogenetic analyses were performed including species of the Dactylogyridae, which were polarized using Monocotylidae as an outgroup.

The JModelTest 2.1.1 program (Posada, 2008) was used to select the most appropriate evolutionary model for Maximum Likelihood (ML) and Bayesian inference (BI). Prior to ML analysis the best-fitting models of nucleotide substitution were determined based on Akaike Information Criteria (AIC) using jModelTest 2.1.1 (Posada, 2008), with GTR+I+G for the partial LSU gene. The supports for ML were determined by performing 100 bootstrap replicates.

Bayesian inference (BI) was performed using the BEAST program (Drummond et al., 2012) and run with a GTR $+\mathrm{I}$ $+G$ nucleotide substitution model. Markov Chain Monte Carlo (MCMC) chains were run for 50 million generations and the log-likelihood scores plotted. Only the final 75\% of trees were used to produce the consensus trees by setting the burn-in parameter at 5 million generations. Phylogenetic trees were generated and edited in FigTree v.1.3.1 (Rambaut, 2009).

\section{Results}

Demidospermus spirophallus $n . s p$.

Dactylogyridae Bychowsky, 1933; Demidospermus Suriano, 1983. 
Table 1. Species of the Dactylogyridae of siluriforms used in the present study, with details of locality, host and GenBank accession numbers.

\begin{tabular}{|c|c|c|c|c|}
\hline Parasite & Host & Locality & GenBank & Reference \\
\hline \multicolumn{5}{|l|}{ Dactylogyridae } \\
\hline \multicolumn{5}{|l|}{ Ancyrocephalinae } \\
\hline Ameloblastella chavarriai & Rhamdia quelen & Catemaco Lake, Mexico & КР056251 & $\begin{array}{l}\text { Mendoza-Palmero et al., } \\
2015\end{array}$ \\
\hline $\begin{array}{l}\text { Ameloblastella edentensis } \\
\quad(=\text { Ameloblastella } \text { sp. } 16)\end{array}$ & $\begin{array}{l}\text { Hypophthalmus } \\
\text { edentatus }\end{array}$ & Nanay River, Peru & KP056255 & $\begin{array}{l}\text { Mendoza-Palmero et al., } \\
2015\end{array}$ \\
\hline Ameloblastella sp. 23 & $\begin{array}{l}\text { Hypophthalmus } \\
\text { edentatus }\end{array}$ & Nanay River, Peru & KР056233 & $\begin{array}{l}\text { Mendoza-Palmero et al., } \\
2015\end{array}$ \\
\hline Aphanoblastella aurorae & Goeldiella eques & Santa Clara, Peru & KР056239 & $\begin{array}{l}\text { Mendoza-Palmero et al., } \\
2015\end{array}$ \\
\hline Aphanoblastella sp. 3 & Goeldiella eques & Nanay River, Peru & KР056238 & $\begin{array}{l}\text { Mendoza-Palmero et al., } \\
2015\end{array}$ \\
\hline $\begin{array}{l}\text { Cosmetocleithrum bifurcum } \\
\text { (= Cosmetocleithrum } \mathrm{sp} .8)\end{array}$ & Hassar orestis & Aquarium Momón River, Peru & КР056216 & $\begin{array}{l}\text { Mendoza-Palmero et al., } \\
2015\end{array}$ \\
\hline Demidospermus anus (1-2) & $\begin{array}{l}\text { Loricariichthys } \\
\text { platymetopon }\end{array}$ & Upper Paraná River floodplain & $\begin{array}{l}\text { (1): KY766956 } \\
\text { (2): KY766957 }\end{array}$ & Present study \\
\hline $\begin{array}{l}\text { Demidospermus } \\
\text { spirophallus } \mathrm{n} . \mathrm{sp} .\end{array}$ & Loricaria prolixa & Sapucaí-Mirim River, Brazil & KY766954 & Present study \\
\hline $\begin{array}{l}\text { Demidospermus } \\
\text { mortenthaleri }\end{array}$ & $\begin{array}{l}\text { Brachyplatystoma } \\
\text { juruense }\end{array}$ & Santa Clara, Peru & КР056245 & $\begin{array}{l}\text { Mendoza-Palmero et al., } \\
2015\end{array}$ \\
\hline $\begin{array}{l}\text { Demidospermus prolixus } \\
\text { n. sp. }\end{array}$ & Loricaria prolixa & Sapucaí-Mirim River, Brazil & KY766955 & Present study \\
\hline Demidospermus sp. 11 & $\begin{array}{l}\text { Brachyplatystoma } \\
\text { vaillantii }\end{array}$ & Nanay River, Peru & КР056235 & $\begin{array}{l}\text { Mendoza-Palmero et al., } \\
2015\end{array}$ \\
\hline Demidospermus sp. 23 & $\begin{array}{l}\text { Brachyplatystoma } \\
\text { vaillantii }\end{array}$ & Nanay River, Peru & КР056236 & $\begin{array}{l}\text { Mendoza-Palmero et al., } \\
2015\end{array}$ \\
\hline Ligictaluridus pricei & Ameiurus nebulosus & Moldau River, Czech Republic & AJ969939 & Simková et al., 2006 \\
\hline Unibarra paranoplatensis & Aguarunichthys torosus & Santa Clara, Peru & КР056219 & $\begin{array}{l}\text { Mendoza-Palmero et al., } \\
2015\end{array}$ \\
\hline Vancleaveus januacaensis & Pterodoras granulosus & Itaya River, Peru & КР056247 & $\begin{array}{l}\text { Mendoza-Palmero et al., } \\
2015\end{array}$ \\
\hline \multicolumn{5}{|l|}{ Ancylodiscoidinae } \\
\hline Bychowskyella pseudobagri & Tachysurus fulvidraco & Shaoguan, China & EF100541 & Wu et al., 2008 \\
\hline Chauhanellus boegeri & Genidens genidens & Antonina Bay, Brazil & КР056241 & $\begin{array}{l}\text { Mendoza-Palmero et al., } \\
2015\end{array}$ \\
\hline Chauhanellus sp. & Genidens genidens & Antonina Bay, Brazil & КР056242 & $\begin{array}{l}\text { Mendoza-Palmero et al., } \\
2015\end{array}$ \\
\hline Quadriacanthus kobiensis & Clarias batrachus & Guanzhou, China & AY841874 & $\begin{array}{l}\text { Ding \& Liao, } 2005 \\
\text { (unpublished) }\end{array}$ \\
\hline Schilbetrema sp. & Pareutropius debauwi & $\begin{array}{l}\text { Aquarium from Czech Republic, } \\
\text { origin West Africa }\end{array}$ & KР056243 & $\begin{array}{l}\text { Mendoza-Palmero et al., } \\
2015\end{array}$ \\
\hline Thaparocleidus asoti & Silurus asotus & Rongchang, China & DQ157669 & Wu et al., 2006 \\
\hline Thaparocleidus cochleavagina & Silurus asotus & Rongchang, China & EF100547 & Wu et al., 2008 \\
\hline $\begin{array}{l}\text { Thaparocleidus } \\
\text { infundibulovagina }\end{array}$ & Silurus asotus & Rongchang, China & EF100548 & Wu et al., 2008 \\
\hline Thaparocleidus magnicirrus & Silurus asotus & Kaiping, China & EF100549 & Wu et al., 2008 \\
\hline Thaparocleidus siluri & Silurus ganis & Morava River, Czech Republic & AJ969940 & Simková et al., 2006 \\
\hline Thaparocleidus sp. & Pangasius sp. & $\begin{array}{l}\text { Aquarium from Czech Republic, } \\
\text { origin Asia }\end{array}$ & KР056249 & $\begin{array}{l}\text { Mendoza-Palmero et al., } \\
2015\end{array}$ \\
\hline Thaparocleidus sp. & Pangasius sp. & $\begin{array}{l}\text { Aquarium from Czech Republic, } \\
\text { origin Asia }\end{array}$ & KР056250 & $\begin{array}{l}\text { Mendoza-Palmero et al., } \\
2015\end{array}$ \\
\hline Thaparocleidus sp. & Silurus asotus & Chongqing, China & DQ157670 & Wu et al., 2006 \\
\hline Thaparocleidus varicus & Silurus asotus & Chongqing, China & DQ157668 & Wu et al., 2006 \\
\hline \multicolumn{5}{|l|}{ Dactylogyrinae } \\
\hline Dactylogyridae gen. sp. 4 & Ageneiosus vittatus & Nanay River, Peru & КР056218 & $\begin{array}{l}\text { Mendoza-Palmero et al., } \\
2015\end{array}$ \\
\hline Dactylogyridae gen. sp. 9 & $\begin{array}{l}\text { Platynematichthys } \\
\text { notatus }\end{array}$ & Santa Clara, Peru & $\begin{array}{l}\text { KP056220, 21, } \\
\quad 23-24\end{array}$ & $\begin{array}{l}\text { Mendoza-Palmero et al., } \\
2015\end{array}$ \\
\hline Dactylogyridae gen. sp. 10 & $\begin{array}{l}\text { Platynematichthys } \\
\text { notatus }\end{array}$ & Santa Clara, Peru & KР056225-26 & $\begin{array}{l}\text { Mendoza-Palmero et al., } \\
2015\end{array}$ \\
\hline Dactylogyridae gen. sp. 12 & Sorubim lima & Iquitos-Belém, Peru & KР056228 & $\begin{array}{l}\text { Mendoza-Palmero et al., } \\
2015\end{array}$ \\
\hline
\end{tabular}


Table 1. (Cont.)

\begin{tabular}{|c|c|c|c|c|}
\hline Parasite & Host & Locality & GenBank & Reference \\
\hline Dactylogyridae gen. sp. 13 & $\begin{array}{l}\text { Hypophtalmus } \\
\text { edentatus }\end{array}$ & Nanay River, Peru & KP056229-30 & $\begin{array}{l}\text { Mendoza-Palmero et al., } \\
2015\end{array}$ \\
\hline Dactylogyridae gen. sp. 18 & $\begin{array}{l}\text { Pseudoplatystoma } \\
\text { fasciatum }\end{array}$ & Santa Clara, Peru & КР056231 & $\begin{array}{l}\text { Mendoza-Palmero et al., } \\
2015\end{array}$ \\
\hline Dactylogyridae gen. sp. 23 & Platysilurus mucosus & Santa Clara, Peru & KР056232 & $\begin{array}{l}\text { Mendoza-Palmero et al., } \\
2015\end{array}$ \\
\hline Dactylogyridae gen. sp. 26 & $\begin{array}{l}\text { Platynematichthys } \\
\text { notatus }\end{array}$ & Santa Clara, Peru & КР056234 & $\begin{array}{l}\text { Mendoza-Palmero et al., } \\
2015\end{array}$ \\
\hline \multicolumn{5}{|l|}{ Monocotylidae } \\
\hline $\begin{array}{l}\text { Dictyocotyle coeliaca } \\
\quad \text { (= Decacotyle lymmae) }\end{array}$ & Aetobatus narinari & Heron Island, Australia & AF348359 & Chisholm et al., 2001 \\
\hline
\end{tabular}

\section{Description}

Based on 13 specimens mounted in Gray and Wess and 10 specimens stained with Gömöri trichrome and mounted in Canada balsam (fig. 1a-i). Body elongated, fusiform, 880 (670-1225; $n=8)$ long, divisible into cephalic region, trunk, short peduncle and haptor. Greatest width 125 (89-177; $n=$ 12) at level of testis. Two terminal and two bilateral cephalic lobes, moderately developed. Three bilateral pairs of head organs; cephalic glands in the pharyngeal region. Eyes and accessory eyespot granules absent. Pharynx subspherical, 43 (33-53; $n=12)$ long, 45 (24-60; $n=12)$ wide. Oesophagus short, intestinal caecum confluent posterior to gonads. Counterclockwise-coiled male copulatory organ (MCO), $212(193-230 ; n=11)$ long, with 21/2 rings, proximal ring $21(18-22 ; n=10)$ in diameter. Sheath-like accessory piece serving as guide for the $\mathrm{MCO}$, with one of the ends bifurcated, 53 (49-57; $n=5)$ long. Gonads in tandem, ovary pretesticular. Testis elongated $254(n=1)$ long and 150 ( $n=1)$ wide; between the intestinal caeca. Vas deferens conspicuous, looping around left intestinal caecum. Seminal vesicle a distal dilatation of vas deferens, with great variation of forms. Oviduct, ootype, uterus not observed. Ovary $52(40-65 ; n=4)$ long, $59(21-86 ; n=4)$ wide. Egg oval with a small posterior filament. Seminal receptacle anterior to ovary. Sinistral vagina aperture weakly sclerotized, curved and tubular, opening into subspherical seminal receptacle through a weakly sclerotized duct. Vitelline follicles densely scattered throughout trunk, absent in region of reproductive organs. Haptor 106 (63$135 ; n=10)$ long and $136(84-206 ; n=10)$ wide, with two pairs of anchors and two bars. Anchors with welldeveloped superficial root, short deep root, short and straight shaft, and elongated straight point. Dorsal anchor $32(29-37 ; n=11)$ long (fig. 2a), base $26(24-28 ; n=11)$ wide (fig. 2b) and root 16 (13-19; $n=11$ ) wide (fig. 2c). Ventral anchor $28(25-31 ; n=12)$ long; short, deep root; root $18(20-25 ; n=12)$ wide and base $24(20-26 ; n=12)$ wide. Bars with medial narrowing in the base and variable aperture and distance between ends. Dorsal bar ' $\mathrm{V}$ ' wide open-shaped, articulate, with variable aperture of angulation, distance between ends $58(23-76 ; n=11)$ (fig. 2d), 81 (73-99; $n=11)$ total length (fig. 2e) and $24(14-38 ; n=11)$ height. Ventral bar ' $V$ ' shaped with ends laterally directed, with an evident narrowing in the middle and varying aperture of angulation; $89(78-102 ; n=12)$ total length, distance between ends $61(24-97 ; n=11)$ and $29(14-37 ; n=11)$ height. Seven pairs of hooks, similar in form and size, with distribution as proposed by Mizelle (1936), each with a recurved point, delicate throughout; protruding thumb, and filamentous hooklet loop approaching threequarters of shank length. Shanks of hooks were 8 (6-9; $n=11)$ long, and hooklets 4 (3-5; $n=11)$ long.

\section{Taxonomic summary}

Type host. Loricaria prolixa Isbrücker \& Nijssen, 1978 (Siluriformes, Loricariidae).

Type locality. Sapucaí-Mirim River $\left(20^{\circ} 29^{\prime} 38.38^{\prime \prime S}, 47^{\circ} 51^{\prime}\right.$ 33.11"W), municipality of São Joaquim da Barra, state of São Paulo, Brazil.

\section{Site of infection. Gills.}

Infection rate. Prevalence: $98.0 \%$; mean intensity of infection: $92.5 \pm 10.5$ (9.0-400.0); mean abundance: $90.7 \pm 10.5$ (0-400.0).

Specimens deposited. Holotype CHIOC (38611a); paratypes CHIOC (38611b-d); vouchers INPA (705 a-d) and CHIBB (226L-232L).

Etymology. The specific epithet is from the Latin and is derived from the coiled disposition of the male copulatory organ (MCO) (spiro = anything wound up or coiled + phallus $=$ penis $)$.

\section{Remarks}

Demidospermus spirophallus n. sp. was included in the genus proposed by Suriano (1983) based on agreement with the amended generic characteristics of the diagnosis presented by Kritsky \& Gutiérrez (1998), such as the tubular MCO with a sheath-like accessory piece, sinistral vagina, the absence of eyes or accessory granules, gonads in tandem, and ventral and dorsal bars shaped in either 'U' or ' $\mathrm{V}$ ' forms. In D. spirophallus n. sp., the bars showed varied opening angles, depending on the mounting of the permanent slides.

This new species differs from its congeners mainly due to the morphology, diameter and number of rings of the counterclockwise-coiled male copulatory organ (MCO); the accessory piece, the shape of the vagina and the presence of a weakly sclerotized duct that composes the seminal receptacle. The sinistral vagina is tubular, curved, 


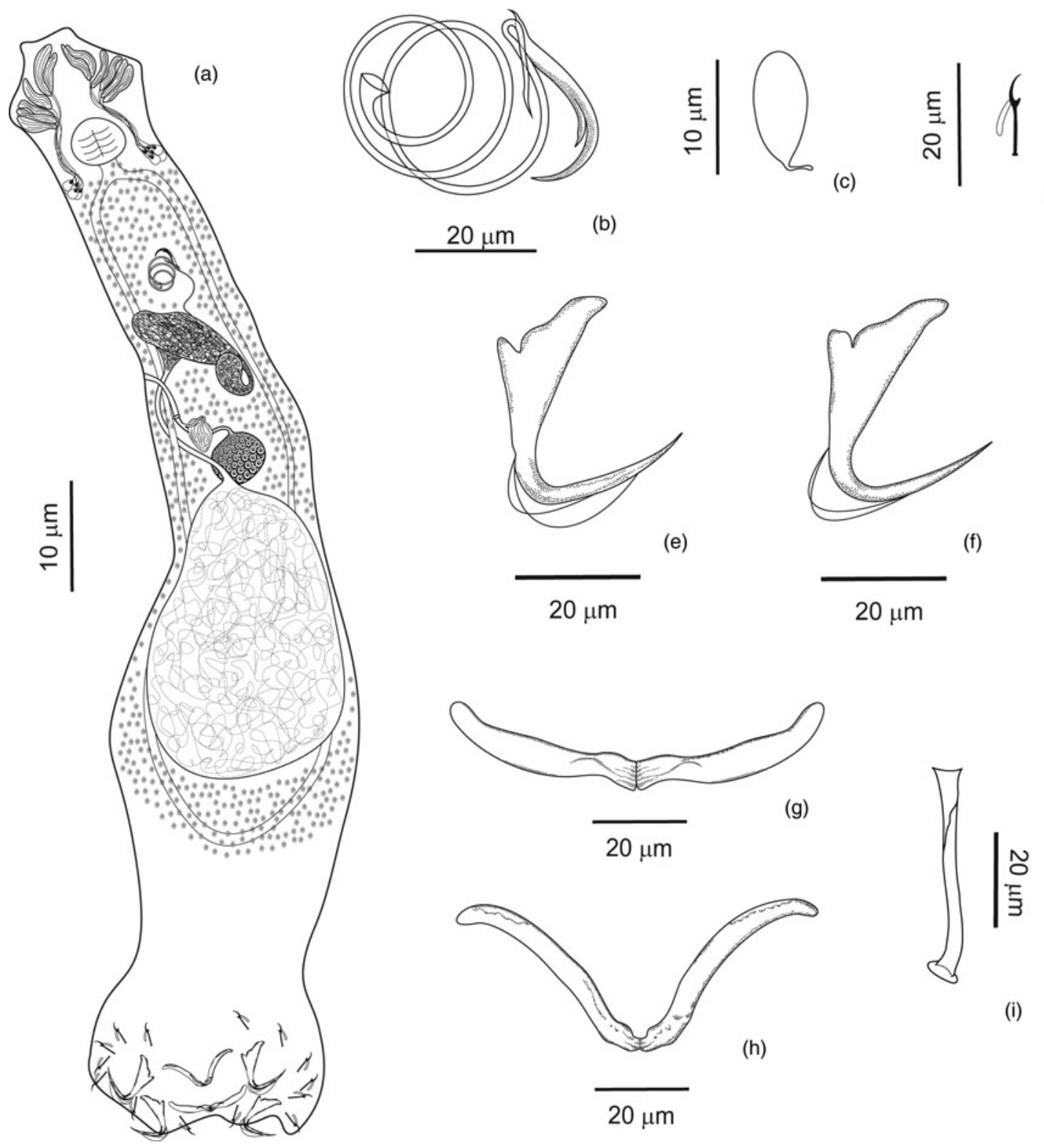

Fig. 1. Morphology of Demidospermus spirophallus n. sp., showing: (a) entire body, dorsal view (composite); (b) copulatory complex, ventral view; (c) egg; (d) hook; (e) dorsal anchor; (f) ventral anchor; (g) dorsal bar; (h) ventral bar; and (i) vagina, dorsal view.

delicate, weakly sclerotized, opening into a small seminal receptacle with a pouch-like shape, throughout a weakly sclerotized duct, versus the non-sclerotized vagina described in other species in this genus, such as D. luckyi (Kritsky, Thatcher \& Boeger, 1987) (= Omothecium luckyi), D. pinirampi (Kritsky, Thatcher \& Boeger, 1987) (= Omothecium pinirampi), D. ceccarellii Cepeda \& Luque, 2010 and D. brachyplatystomae Cepeda \& Luque, 2010. The presence of the sclerotized duct as part of the seminal receptacle has never been described before in Demidospermus specimens.

The MCO of this new species has $2 \frac{1 / 2}{2}$ rings and the accessory piece is tubular, with one bifurcated end, while the accessory piece of the type species $D$. anus is composed of only one sclerotized piece, the number of the cirrus rings is lower $\left(1 \frac{1 / 2}{2}\right)$ and the diameter of the rings are greater than in D. spirophallus n. sp. The species D. paranaensis, described parasitizing a loricariid from Brazil, also exhibits a counterclockwise-coiled MCO, although the cirrus is composed of just $1 \frac{1}{2}$ rings, long and elliptical shaped, and its tegument presents conspicuous annulations throughout the trunk and peduncle (inconspicuous in D. spirophallus n. sp.). Although some species of the same genus may present the cirrus as a sigmoid tube (D. centromochli Mendoza-Franco \& Scholz, 2009), C-shaped (D. ichthyocercus Monteiro, Kritsky \& Brasil-Sato, 2010) or a short and robust tube (D. brevicirrus Mendoza-Palmero, Scholz, Mendoza-Franco \& Kuchta, 2012), the majority have a counterclockwise-coiled MCO. 


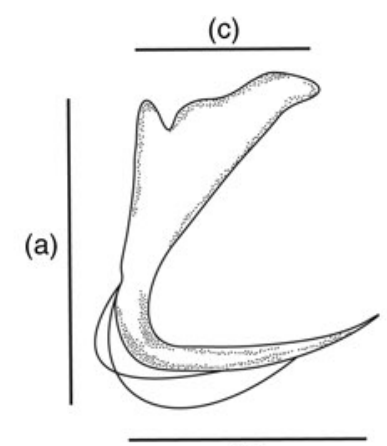

(b)

\section{$20 \mu \mathrm{m}$}

(d)

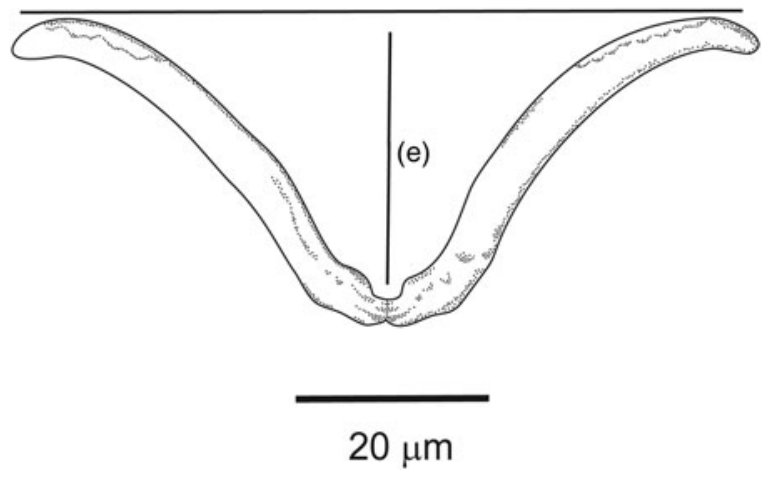

Fig. 2. Anchor and bar of Demidospermus spirophallus n. sp., showing: (a) length of superficial root to base; (b) width of base; (c) root width; (d) distance between ends; and (e) bar length.

Demidospermus spirophallus $\mathrm{n}$. sp., as well as D. paranaensis, D. anus, D. ichthyocercus and D. centromochli, present no differences in terms of the morphology of the haptoral hooks, unlike some of its congeners (e.g. D. macropteri Mendoza-Franco \& Scholz, 2009, D. peruvianus Mendoza-Palmero \& Scholz, 2011, D. curvovaginatus Mendoza-Palmero \& Scholz, 2011, D. striatus Mendoza-Palmero \& Scholz, 2011, D. lebedevi (Kritsky \& Thatcher, 1976), D. brevicirrus, D. mortenthaleri and D. pinirampi).

Although D. lebedevi also shows a cirrus composed of circular rings, it has 2-3 rings with a greater diameter (72 (56-83)) than those of D. spirophallus n. $\mathrm{sp}$. Furthermore, D. lebedevi has eyes and an accessory eyespot, which are absent in the new species.

\section{Demidospermus prolixus $n . s p$.}

\section{Description}

Based on two specimens mounted in Gray and Wess, five in Hoyer and one stained with Gömöri trichrome and mounted in Canada balsam (fig. 3a-h). Body elongated, fusiform, 747 (416-987; $n=7$ ) long, divisible into cephalic region, trunk, short peduncle and haptor.
Greatest width $119(109-130 ; n=7)$ at level of testis. Two terminal and two bilateral cephalic lobes, moderately developed. Three bilateral pairs of head organs; cephalic glands in the pharyngeal region. Eyes and accessory eyespot granules absent. Pharynx subspherical, 37 (34-48; $n=7)$ long; 31 (25-58; $n=7)$ wide. Oesophagus short, intestinal caecum confluent posterior to gonads. Counterclockwise-coiled male copulatory organ (MCO), $223(210-234 ; n=7)$ long, and 11/2 rings, $66(60-74 ; n=7)$ long and $27(20-31 ; n=7)$ wide. Accessory piece straight and strongly sclerotized, groove-like, $36(32-38, n=7)$ long. Gonads in tandem, ovary pretesticular. Testis elongated $138(113-164 ; n=2)$ long and $64(54-74 ; n=2)$ wide; between the intestinal caeca. Vas deferens conspicuous, looping around left intestinal caecum. Seminal vesicle a distal dilatation of vas deferens, with great variation in forms. Oviduct, ootype, uterus not observed. Egg oval, $106(100-112 ; n=2)$ long and $52(49-54 ; n=2)$ wide, with a posterior filament, $52(45-58 ; n=2)$ long. Seminal receptacle not observed. Sinistral vagina aperture non-sclerotized. Vitelline follicles densely scattered throughout trunk, below the pharynx and anteriorly to the peduncle. Haptor $78(60-103 ; n=7)$ long and 170 (152-205; $n=7)$ wide, slightly subtrapezoidal, with two pairs of anchors and two bars. Anchors with welldeveloped superficial root; short, deep root; short and curved shaft. Ventral anchor $36(34-38 ; n=5)$ long; root $15(13-16 ; n=7)$ wide and base $19(16-22 ; n=7)$ wide. Dorsal anchor $36(34-39 ; n=5)$ long; root $15(13-16 ; n=5)$ wide, and base $21(20-24 ; n=6)$ wide. Bars with medial narrowing in the base and variable aperture and distance between ends. Ventral bar ' $\mathrm{V}$ ' wide open-shaped, articulate, with variable aperture of angulation (conspicuously more open than the dorsal bar), total length $85(83-86 ; n=$ 5), distance between ends $73(71-80 ; n=5)$ and $19(11-26$; $n=5$ ) height. Dorsal bar ' $V$ ' shaped, with an evident narrowing in the middle and varying aperture of angulation; $72(70-73 ; n=5)$ total length, distance between ends 39 $(31-47 ; n=5)$ and height $30(28-33 ; n=5)$. Seven pairs of hooks, dissimilar in terms of the shank size: hook pairs 1-6 are similar (shanks $9(8-10 ; n=15)$ long and hooklets 5 (4-6; $n=15)$ long), but hook pair 7 presents a longer shank (shanks $13(10-14 ; n=15)$ long and hooklets 6 (5$7 ; n=15)$ long). The hook distribution is as proposed by Mizelle (1936), each with a recurved point, delicate throughout; protruding thumb and filamentous hooklet loop approaching half the shank length.

\section{Taxonomic summary}

Type host. Loricaria prolixa Isbrücker \& Nijssen, 1978 (Siluriformes, Loricariidae).

Type locality. Sapucaí-Mirim River $\left(20^{\circ} 29^{\prime} 38.38^{\prime \prime} \mathrm{S}, 47^{\circ} 51^{\prime}\right.$ 33.11"W), municipality of São Joaquim da Barra, state of São Paulo, Brazil.

\section{Site of infection. Gills.}

Infection rate. Prevalence: $98.0 \%$; mean intensity of infection: $169.4 \pm 19.3$ (16.0-732.0); and mean abundance: 166.0 $\pm 19.2(0-732.0)$. 


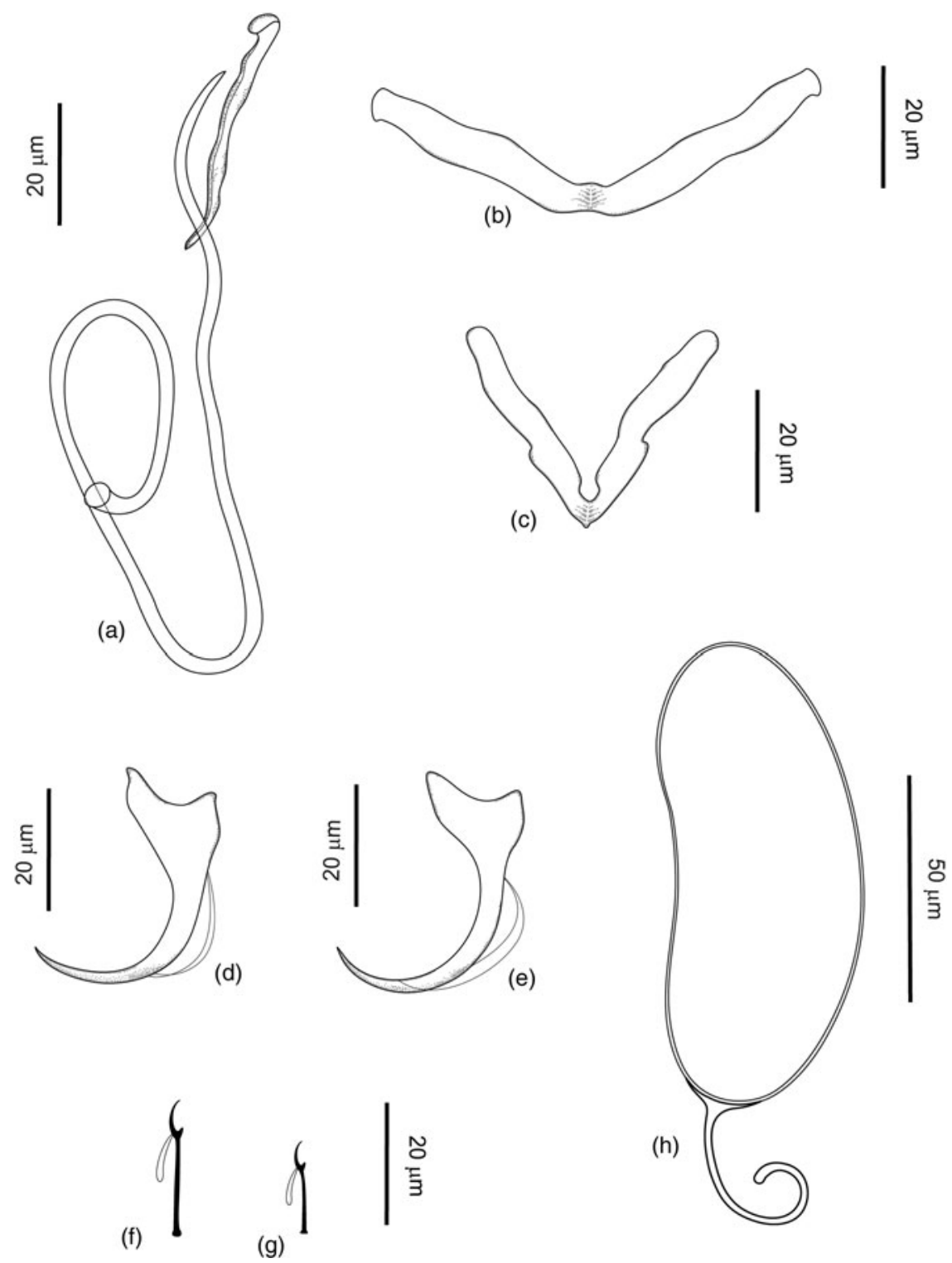

Fig. 3. Morphology of Demidospermus prolixus n. sp., showing: (a) copulatory complex, ventral view; (b) ventral bar; (c) dorsal bar; (d) dorsal anchor; (e) ventral anchor; (f) hook pair 7; (g) shape of hook pairs 1-6; (h) egg.

Specimens deposited. Holotype CHIOC (38609a); paratype CHIOC (38609b-c; 38610); vouchers INPA (704 a-e) and CHIBB (233L-236L).

Etymology. The specific epithet is derived from the name of the type host (Loricaria prolixa).

\section{Remarks}

Demidospermus prolixus n. sp., as well as D. spirophallus n. sp., was included in this genus based on agreement with the amended generic characteristics of the diagnosis presented by Kritsky \& Gutiérrez (1998), previously cited. The morphology of the copulatory complex of this new species is very similar to that of $D$. paranaensis described by Ferrari-Hoeinghaus et al. (2010) from L. platymetopon, as the presence of a longer, counterclockwise-coiled $\mathrm{MCO}$, with an ovate base and non-articulated groove-like accessory piece serving as a MCO guide. However, the $\mathrm{MCO}$ and the accessory piece are more robust and larger than those observed in D. paranaensis.

This new species differs from other congeners mainly due to the morphology of the bars (dorsal bar with conspicuous protuberances), two different hook shapes (fig. 3a-g), and inconspicuous tegumental annulations (conspicuous in D. paranaensis). Demidospermus prolixus n. sp. shares the presence of a non-sclerotized vagina with other congeners, such as D. pinirampi, D. luckyi, 
(a)

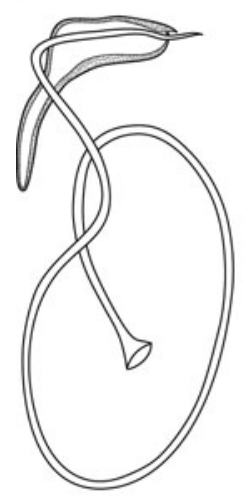

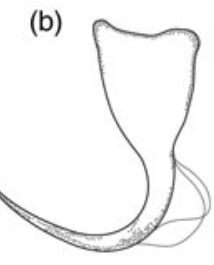

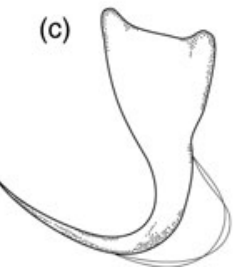

(d)
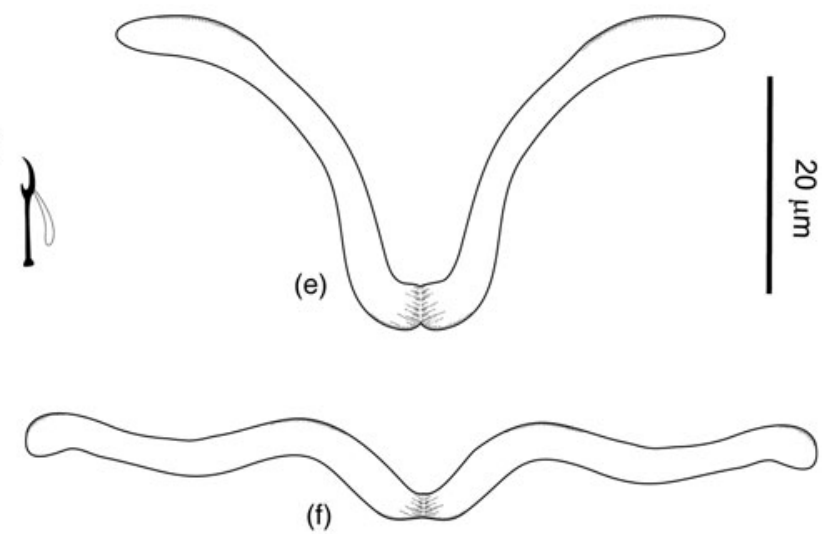

Fig. 4. Morphology of Demidospermus anus, dorsal view: (a) copulatory complex; (b) ventral anchor; (c) dorsal anchor; (d) hook; (e) dorsal bar; and (f) ventral bar.

D. ceccarellii and D. brachyplatystomae, and has no eyes or accessory eyespots, like D. anus, D. paranaensis, D. macropteri and D, spirophallus n. sp. However, other congeners have subspherical eyespots and/or scattered granules.

Demidospermus anus Suriano, 1983

\section{Redescription}

Characteristics based on two specimens mounted in Gray and Wess, and six specimens mounted in Hoyer (fig. 4a-f). Body elongated, fusiform, 356 (319-392; $n=3$ ) long, divisible into cephalic region, trunk, short peduncle and haptor. Greatest width $65(55-75 ; n=3)$ at level of testis. Two terminal and two bilateral cephalic lobes, moderately developed. Three bilateral pairs of head organs; cephalic glands in the pharyngeal region. Eyes and accessory eyespot granules absent. Pharynx subspherical, 28 $(24-32 ; n=4)$ long. Oesophagus short, intestinal caecum confluent posterior to gonads. Counterclockwise-coiled male copulatory organ (MCO), $152(143-156 ; n=5)$ long, curved tube, with variable diameter and loop number (1-1 $1 \frac{1}{2}$ rings), depending on the mounting slide. Sheathlike accessory piece serving as guide for the $\mathrm{MCO}, 31$ (30-33; $n=5)$ long. Gonads intercaecal, tandem; ovary pretesticular. Vas deferens conspicuous, looping around left intestinal caecum; seminal vesicle a distal dilatation of vas deferens. Oviduct, ootype, uterus not observed. Sinistral vagina aperture weakly sclerotized, curved and tubular. Vitelline follicles densely scattered throughout trunk, absent in region of reproductive organs. Haptor $48(46-52 ; n=3)$ long and $71(69-73 ; n=3)$ wide, with two pairs of anchors and two bars. Anchors with short superficial root, deep root, short and straight shaft. Ventral and dorsal anchors similar, $20(19-21 ; n=4)$ long; base $15(14-16 ; n=4)$ wide; and root $11(10-12 ; n=4)$ wide. Dorsal bar ' $V$ ' shaped, wide, open-shaped, articulate, with medial narrowing in the base and variable aperture and distance between ends, $60(50-70 ; n=3)$ total length. Ventral bar ' $\mathrm{V}$ ' shaped, more open than the dorsal bar, with an evident narrowing in the middle; 65 (60-70; $n=3$ ) total length. Seven pairs of hooks, similar in form and size, $11(10-12 ; n=8)$ total length, with distribution as proposed by Mizelle (1936), each with a recurved point, delicate throughout; protruding thumb and filamentous hooklet loop approaching three-quarters of shank length.

\section{Taxonomic summary}

Type host. Loricariichthys anus (Valenciennes, 1835) (=Loricaria anus) (Siluriformes, Loricariidae).

Type locality. Laguna de Chascomús $\left(35^{\circ} 37^{\prime} \mathrm{S}, 58^{\circ} 04^{\prime} \mathrm{W}\right)$, Province of Buenos Aires, Argentina.

Site of infection. Gills.

Material studied (present study). Eight specimens from Loricariichthys platymetopon Isbrücker \& Nijssen, 1979 (Siluriformes, Loricariidae), collected in June 2016 in the Upper Paraná River floodplain, near the municipality of

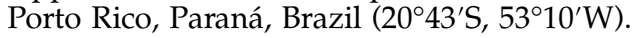

Specimens deposited. Vouchers CHIOC (38608 a-e), INPA (703 a-d) and CHIBB (237L-243L).

Additional hosts. Loricariichthys platymetopon from the reservoir of Itaipu Hydroelectric Power Station, Paraná, Brazil (Cohen \& Kohn, 2008).

\section{Remarks}

Demidospermus was proposed by Suriano (1983) with $D$. anus as the type species. However, as described by the authors, the holotype, paratypes or vouchers of the type species were never deposited at the Helminthological Section of the Museo de La Plata, Argentina. The scarcity of information about this material, its incomplete description and the absence of sequences of the type species 
make studies of this monogenean genus difficult, and represent a problem in its circumscription.

Ferrari-Hoeinghaus et al. (2010) described the species $D$. paranaensis from L. platymetopon collected in the Upper Paraná River floodplain, which is the same reservoir and the same host species from which the specimens of $D$. anus analysed in the present study were collected. In another study, Cohen \& Kohn (2008) reported, for the first time, the occurrence of $D$. anus in L. platymetopon from the reservoir of the Itaipu Hydroelectric Power Station, Brazil. Ferrari-Hoeinghaus et al. (2010) considered that $D$. paranaensis differed from $D$. anus mainly based on the presence of annulations in the tegument (present in $D$. paranaensis and not described in $D$. anus), the size of the haptoral pieces and the morphology of the MCO. However, analysing the paratypes of $D$. paranaensis deposited in the CHIOC and the specimens analysed by Cohen \& Kohn (2008) described as D. anus, no differences were found between the morphology and measurements of the specimens. In both cases, all the specimens had annulations in the tegument, an absence of eyespots, and similar morphologies and measurements of the cirrus (124 (123-125; $n=10)$ total length), accessory piece (18 (17-19); $n=5$ ) and haptoral pieces (fig. 4a-f and fig. 5a-f). Moreover, the diameter of the cirrus ring varies greatly, depending on the mounting and compression. Considering that in both cases the gills were removed and fixed in 1:4000 formalin solution, the annulations may be a consequence of the technique used for fixation prior to analysis.

These annulations were not evident in the specimens of $D$. anus analysed in the present study or those analysed by Suriano (1983) and, in both cases, the material was analysed from frozen fish and in vivo, respectively. In general, the morphologies of $D$. paranaensis and $D$. anus analysed in the present study are very similar (figs 4 and 5), including the presence of partially encapsulated sperm, as described by Suriano (1983). However, differences in the morphology of the anchors, and the measurements of the cirrus and accessory piece (greater in D. anus than D. paranaensis) were observed. Careful future morphological and molecular studies are required on these species.

\section{Molecular characterization}

The new partial LSU sequence length varied from $1483 \mathrm{bp}$ for D. spirophallus n. sp., to $1281 \mathrm{bp}$ for $D$. prolixus n. sp., 684 bp for D. anus (1) and 918 bp for D. anus (2). An unambiguous alignment including Dactylogyridae from the Siluriformes available in GenBank spanned 480 positions. A total of 39 monogenean specimens of siluriforms from the Neotropical, Palaearctic, Ethiopian and Oriental regions were used in the analyses (table 1). The ML and BI analyses yielded similar branching topology, with supported values in the most basal and terminal nodes. Tree main clades, A, B, C and D, were observed and corroborated the findings of Mendoza-Palmero et al. (2015) (fig. 6), with a few changes. Clade A comprises parasites of siluriforms from the Neotropical region and Ligictaluridus pricei (Mueller, 1936) a parasite of ictalurid fish from the Czech Republic, introduced to Europe with its host. Clade B consists of all Thaparocleidus spp. and Aphanoblastella spp., forming a polytomic clade related to clades A and B, with strong branching support. Clade C consists of all Dactylogyridae gen. spp. and Demidospermus spp. from the Neotropical region, and Bychowskyella pseudobagri Achmerow, 1952, and Quadriacanthus kobiensis Ha Ky, 1968 from Oriental regions such as China. Demidospermus spirophallus n. sp. and D. prolixus n. sp. parasites of L. prolixa, and specimens of D. anus parasites of L. platymetopon clustered together as sister taxa in a separate clade within the main clade $C$, with high supporting values. Finally, clade D consisted of dactylogyrids from the Neotropical and Ethiopian regions (Chauhanellus spp. from Brazil and Schilbetrema sp. from West Africa). The position of clade D with the
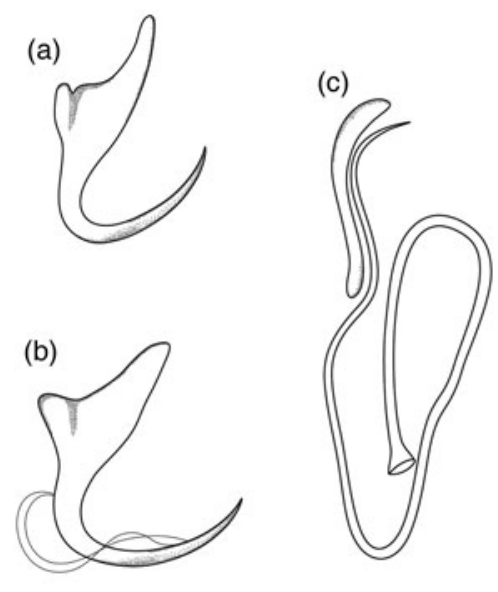

(d)

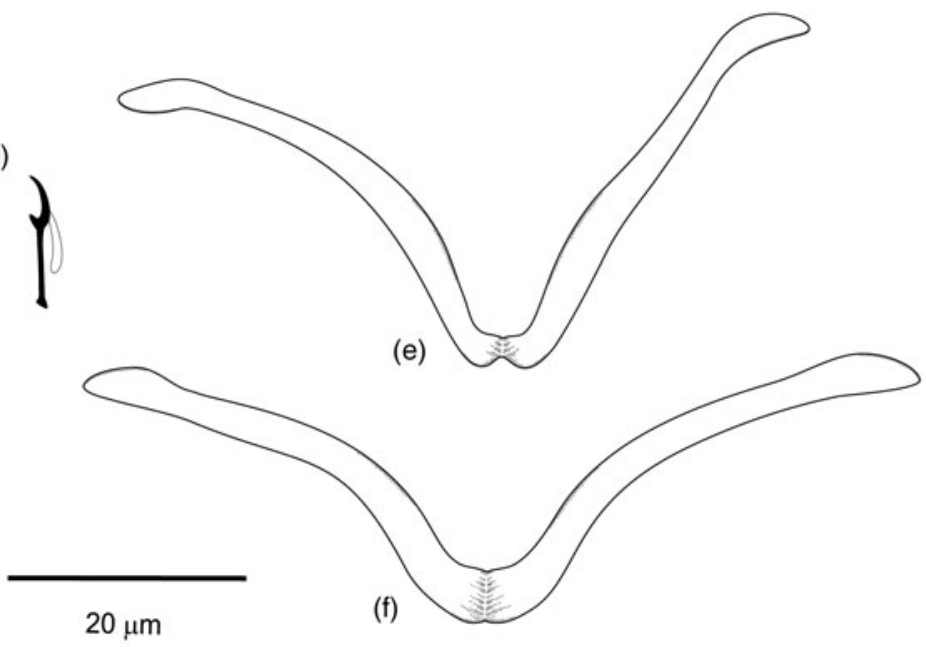

Fig. 5. Morphology of Demidospermus paranaensis, dorsal view: (a) ventral anchor; (b) dorsal anchor; (c) copulatory complex; (d) hook; (e) dorsal bar; and (f) ventral bar. 


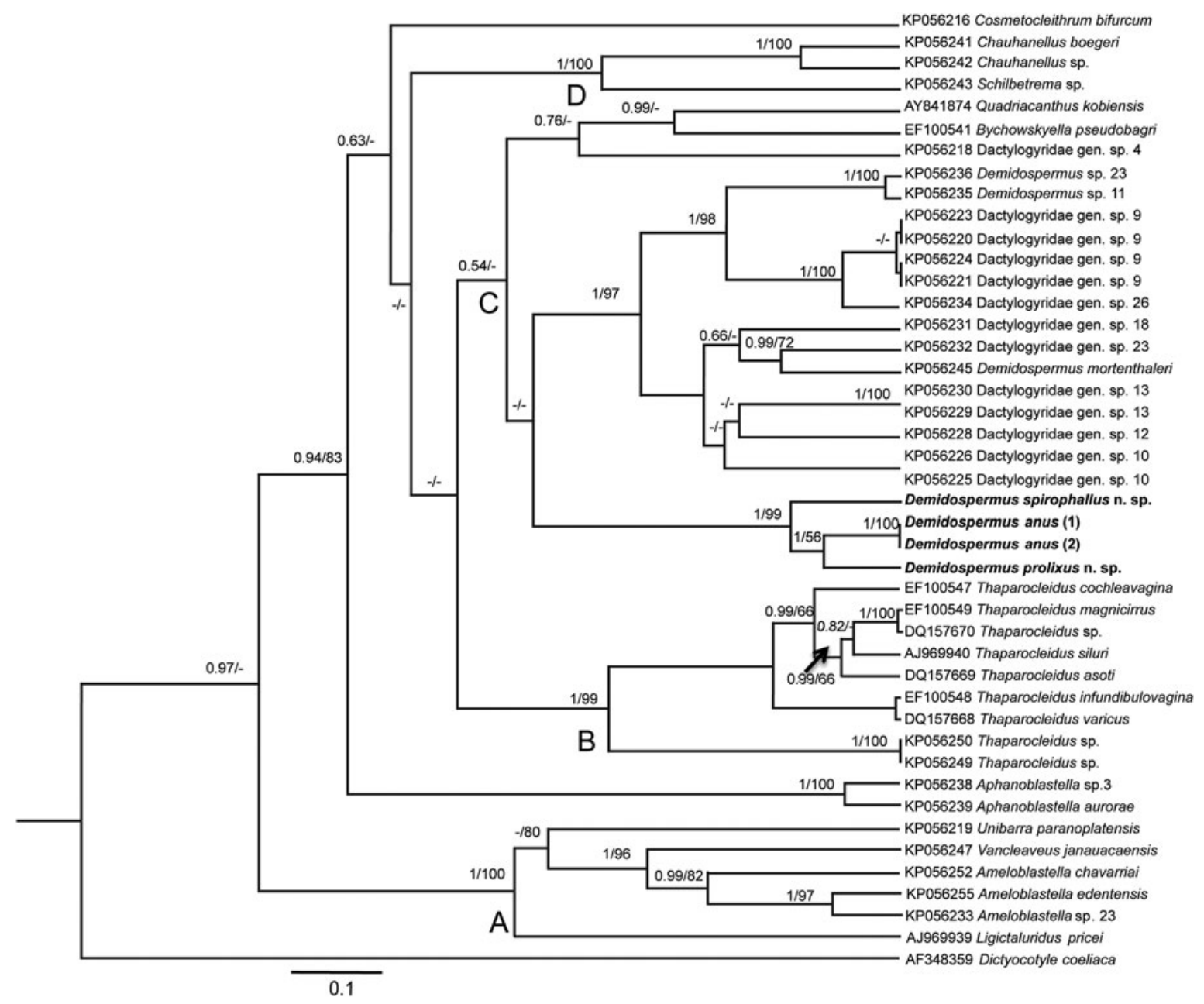

Fig. 6. Bayesian topology based on partial $28 \mathrm{~S}$ ribosomal DNA sequences of Dactylogyridae from siluriforms. GenBank accession numbers precede species names. Support values are above nodes as follows: posterior probabilities for Bayesian analyses and bootstrap for maximum likelihood analyses. Dashes represent branches not supported by analyses (posterior probabilities $<0.50$ and bootstrap scores $<50$ ). Arrow indicates support values above the node. Branch length scale bar indicates number of substitutions per site. The species Dictyocotyle coeliaca (AF348359) was used as an outgroup.

species Chauhanellus sp., Chauhanellus boegeri Domingues and Fehlauer, 2006, and Schilbetrema sp. was not supported, as observed by Mendoza-Palmero et al. (2015). The non-identified Dactylogyridae gen. sp. 4 is allocated differently from that in the study by Mendoza-Palmero et al. (2015), within the Bychowskyella pseudobagri and Quadriacanthus kobiensis clade, with high Bayesian support and low bootstrap. Cosmetocleithrum bifurcum Mendoza-Franco, Mendoza-Palmero \& Scholz, 2016 (= Cosmethocleithrum sp. 8) was not resolved, forming a polytomy.

\section{Discussion}

In addition to the problems regarding the circumscription of the genus Demidospermus due to its incomplete description and the absence of deposited material of the type species, a number of morphological characteristics described in the description of specimens of this genus vary considerably, such as the position of the vaginal opening (sinistral versus dextral; anterior versus medial opening); sclerotized versus non-sclerotized vagina; presence versus absence of eyespots or scattered granules; hook shape (similar morphology versus variable morphology), counterclockwise-coiled versus clockwise MCO. This represents a problem for the accurate identification of the specimens based on morphology, as some characteristics may overlap with those observed in other genera, and perhaps reinforces the possibility that this group is not natural.

The closeness of the phylogenetic relationships of host species has a strong influence on the distribution of monogenean parasites, to the extent that the majority of hosts are susceptible to a specific group of these parasites (Thatcher, 2006; Braga et al., 2014). Neotropical 
Table 2. Species of the genus Demidospermus described in the present study with details of locality, host type and family.

\begin{tabular}{|c|c|c|c|c|}
\hline Species & Type host & Host family & Reference & Locality \\
\hline Demidospermus anus & $\begin{array}{l}\text { Loricariichthys anus (Valenciennes, } \\
\text { 1835) (= Loricaria anus) }\end{array}$ & Loricariidae & Suriano (1983) & Argentina \\
\hline $\begin{array}{l}\text { Demidospermus luckyi } \\
\quad(=\text { Omothecium luckyi) }\end{array}$ & $\begin{array}{l}\text { Pinirampus pirinampu (Spix \& } \\
\quad \text { Agassiz, 1829) }\end{array}$ & Pimelodidae & $\begin{array}{l}\text { Kritsky et al. (1987); Kritsky } \\
\quad \text { \& Gutiérrez (1998) }\end{array}$ & Brazil \\
\hline $\begin{array}{l}\text { Demidospermus pinirampi } \\
\quad(=\text { Omothecium pinirampi })\end{array}$ & Pinirampus pirinampu & Pimelodidae & $\begin{array}{l}\text { Kritsky et al. (1987); Kritsky } \\
\quad \text { \& Gutiérrez (1998) }\end{array}$ & Brazil \\
\hline Demidospermus valenciennesi & $\begin{array}{l}\text { Parapimelodus valenciennis (Lütken, } \\
\text { 1874) (= Parapimelodus } \\
\text { valenciennesi) }\end{array}$ & Pimelodidae & Gutiérrez \& Suriano (1992) & Argentina \\
\hline Demidospermus paravalenciennesi & $\begin{array}{l}\text { Synodontis clarias (Linnaeus, } 1758) \\
\quad(=\text { Pimelodus clarias })^{1}\end{array}$ & Pimelodidae & Gutiérrez \& Suriano (1992) & Argentina \\
\hline Demidospermus uncusvalidus & $\begin{array}{l}\text { Synodontis clarias }{ }^{1} \text { and } \\
\text { Thachelyopterus galeatus } \\
\text { (Linnaeus, 1766) } \\
\text { (=Parauchenipterus galeatus) }\end{array}$ & $\begin{array}{l}\text { Pimelodidae and } \\
\text { Auchenipteridae }\end{array}$ & Gutiérrez \& Suriano (1992) & Argentina \\
\hline $\begin{array}{l}\text { Demidospermus bidiverticulatum } \\
\text { (= Paramphocleithrium } \\
\text { bidiverticulatum Suriano and } \\
\text { Incorvaia, 1995) }\end{array}$ & $\begin{array}{l}\text { Synodontis clarias }{ }^{1} \text { and Pimelodus } \\
\text { albicans (Valenciennes, 1840) }\end{array}$ & Pimelodidae & $\begin{array}{l}\text { Suriano \& Incorvaia (1995); } \\
\text { Kritsky \& Gutiérrez (1998) }\end{array}$ & Argentina \\
\hline Demidospermus armostus & $\begin{array}{l}\text { Synodontis clarias }{ }^{1} \text { and Pimelodus } \\
\quad \text { albicans }\end{array}$ & Pimelodidae & Kritsky \& Gutiérrez (1998) & Argentina \\
\hline Demidospermus corcinus & $\begin{array}{l}\text { Bergiaria westermanni (Lütken, } \\
\text { 1874) (= Iheringichthys } \\
\text { westermanni) }\end{array}$ & Pimelodidae & Kritsky \& Gutiérrez (1998) & Argentina \\
\hline Demidospermus idolus & Pimelodus albicans & Pimelodidae & Kritsky \& Gutiérrez (1998) & Argentina \\
\hline Demidospermus leptosynophallus & Bergiaria westermanni & Pimelodidae & Kritsky \& Gutiérrez (1998) & Argentina \\
\hline Demidospermus majusculus & Pimelodus albicans & Pimelodidae & Kritsky \& Gutiérrez (1998) & Argentina \\
\hline $\begin{array}{l}\text { Demidospermus labrosi } \\
\quad(=\text { Demidospermus corcinus })^{*}\end{array}$ & $\begin{array}{l}\text { Iheringichthys labrosus } \\
\text { (Lütken, 1874) }\end{array}$ & Pimelodidae & França et al. (2003) & Brazil \\
\hline $\begin{array}{l}\text { Demidospermus mandi } \\
\text { (= Demidospermus } \\
\text { leptosynophallus })^{*}\end{array}$ & Iheringichthys labrosus & Pimelodidae & França et al. (2003) & Brazil \\
\hline Demidospermus macropteri & $\begin{array}{l}\text { Calophysus macropterus } \\
\text { (Lichtenstein, 1819) }\end{array}$ & Pimelodidae & $\begin{array}{l}\text { Mendoza-Franco \& Scholz } \\
\text { (2009) }\end{array}$ & Peru \\
\hline Demidospermus centromochli & $\begin{array}{l}\text { Centromochlus heckelii (De Filippi, } \\
\text { 1853) }\end{array}$ & Auchenipteridae & $\begin{array}{l}\text { Mendoza-Franco \& Scholz } \\
\text { (2009) }\end{array}$ & Peru \\
\hline Demidospermus osteomystax & $\begin{array}{l}\text { Auchenipterus osteomystax } \\
\text { (Miranda Ribeiro, 1918) }\end{array}$ & Auchenipteridae & Tavernari et al. (2010) & Brazil \\
\hline Demidospermus ceccarelli & $\begin{array}{l}\text { Brachyplatystoma filamentosum } \\
\text { (Lichtenstein, 1819) }\end{array}$ & Pimelodidae & Cepeda \& Luque (2010) & Brazil \\
\hline $\begin{array}{l}\text { Demidospermus } \\
\text { brachyplatystomae }\end{array}$ & Brachyplatystoma filamentosum & Pimelodidae & Cepeda \& Luque (2010) & Brazil \\
\hline Demidospermus araguaiaensis & Brachyplatystoma filamentosum & Pimelodidae & Cepeda \& Luque (2010) & Brazil \\
\hline Demidospermus ichthyocercus & $\begin{array}{l}\text { Pimelodus maculatus Lacepède, } \\
1803\end{array}$ & Pimelodidae & Monteiro et al. (2010) & Brazil \\
\hline Demidospermus paranaensis & $\begin{array}{l}\text { Loricariichthys platymetopon } \\
\text { Isbrücker \& Nijssen, } 1979\end{array}$ & Loricariidae & $\begin{array}{l}\text { Ferrari-Hoeinghaus et al. } \\
\quad(2010)\end{array}$ & Brazil \\
\hline Demidospermus peruvianus & Pimelodus ornatus Kner, 1858 & Pimelodidae & $\begin{array}{l}\text { Mendoza-Palmero \& Scholz } \\
\text { (2011) }\end{array}$ & Peru \\
\hline Demidospermus curvovaginatus & Pimelodus sp. Lacépède, 1803 & Pimelodidae & $\begin{array}{l}\text { Mendoza-Palmero \& Scholz } \\
\text { (2011) }\end{array}$ & Peru \\
\hline Demidospermus striatus & Pimelodus sp. & Pimelodidae & $\begin{array}{l}\text { Mendoza-Palmero \& Scholz } \\
\text { (2011) }\end{array}$ & Peru \\
\hline $\begin{array}{l}\text { Demidospermus lebedevi } \\
\quad \text { (= Urocleidoides lebedevi) }\end{array}$ & $\begin{array}{l}\text { Pimelodus grosskopfii Steindachner, } \\
\quad 1879\end{array}$ & Pimelodidae & $\begin{array}{l}\text { Kritsky \& Thatcher (1976); } \\
\text { Mendoza-Palmero \& } \\
\text { Scholz (2011) }\end{array}$ & Colombia \\
\hline Demidospermus annulus & Parapimelodus valenciennis & Pimelodidae & $\begin{array}{l}\text { Marcotegui \& Martorelli } \\
\text { (2011) }\end{array}$ & Argentina \\
\hline Demidospermus mortenthaleri & $\begin{array}{l}\text { Brachyplatystoma juruense } \\
\quad \text { (Boulenger, 1898) }\end{array}$ & Pimelodidae & $\begin{array}{l}\text { Mendoza-Palmero et al. } \\
\text { (2012) }\end{array}$ & Peru \\
\hline Demidospermus brevicirrus & Pimelodus sp. & Pimelodidae & $\begin{array}{l}\text { Mendoza-Palmero et al. } \\
\quad \text { (2012) }\end{array}$ & Peru \\
\hline Demidospermus prolixus n. sp. & $\begin{array}{l}\text { Loricaria prolixa Isbrücker \& } \\
\quad \text { Nijssen, } 1978\end{array}$ & Loricariidae & Present study & Brazil \\
\hline
\end{tabular}


Table 2. (Cont.)

\begin{tabular}{llll}
\hline Species & Type host & Host family & Reference \\
\hline $\begin{array}{l}\text { Demidospermus spirophallus } \\
\text { n. sp. }\end{array}$ & $\begin{array}{c}\text { Loricaria prolixa Isbrücker \& } \\
\text { Nijssen, 1978 }\end{array}$ & Loricariidae & Present study \\
\hline
\end{tabular}

*Junior synonyms of Demidospermus leptosynophallus and Demidospermus corcinus, respectively (invalid species).

${ }^{1}$ According to Monteiro et al. (2010), the fish identified as Synodontis clarias (= Pimelodus clarias) is in fact Pimelodus maculatus.

siluriforms, specifically, do not represent a monophyletic assemblage, and include descendants of four independent monophyletic clades (Sullivan et al., 2006; Braga et al., 2014). The origin of their monogenean fauna is unclear, reflecting the differences of the fish lineages that make up this order (Braga et al., 2014). The reports of monogeneans of Demidospermus described until now (29 species) are limited to freshwater siluriforms from the Neotropics (table 2), belonging to the Loricariidae, Pimelodidae and Auchenipteridae families, distributed from the Peruvian Amazon to Argentina. These fish families are not phylogenetically closely related (see Sullivan et al., 2006, and references therein; Mendoza-Palmero \& Scholz, 2011) and the occurrence of some species of Demidospermus parasitizing these fishes, along with recently reported molecular data about these monogeneans (see Mendoza-Palmero et al., 2015), suggest the need to review the species composition of this genus and others that occur in catfishes, for the correct generic assignation of these species.

Ten species belonging to Demidospermus have been recorded in catfishes from Brazil, and other species have been described in fishes collected in Argentina (11 species), Peru (Peruvian Amazon) (7 species) and Colombia (1 species). Among these, only four species of Demidospermus were described specifically from loricariid fishes (table 2), including the type species D. anus. The loricariid recorded as hosts to Demidospermus spp. are L. anus (= Loricaria anus), which was reported as a host to the type species D. anus (Suriano, 1983); L. platymetopon, a host of D. paranaensis (Ferrari-Hoeinghaus et al., 2010) and D. anus (Cohen \& Kohn, 2008); Loricariichthys castaneus (Castelnau, 1855), parasitized with Demidospermus sp. (Azevedo et al., 2010), and L. prolixa, a host of the two new species described in this study.

Mendoza-Palmero et al. (2015), in a study on the phylogeny of Neotropical monogeneans from catfishes (pimelodids), suggested a possible polyphyly of the group, based on the subdivision of the monogeneans into three main clades (A, B and C) within Dactylogyridae. In addition, the authors presented the first molecular data of Demidospermus species (D. mortenthaleri and two other undescribed species - Demidospermus sp. 11 and Demidospermus sp. 23), parasites of the pimelodids B. juruense and $B$. vaillantii, respectively, from Iquitos, Peru. However, observing their phylogenic results and carefully analysing the morphology of $D$. mortenthaleri (see Mendoza-Palmero et al., 2012), and other species of Demidospermus described parasitizing Brachyplatystoma filamentosum (Lichtenstein, 1819) from Brazil (Cepeda \& Luque, 2010) (D. ceccarelli, D. brachyplatystomae and D. araguaiaensis), we hypothesize that these species do not in fact belong to this genus, and so should be included in a new genus. Although these species resemble each other, they show conspicuous differences in terms of the diagnostic characteristics of the Demidospermus genus (e.g. bar shapes). The same may have occurred with the undescribed species, namely Demidospermus sp. 11 and Demidospermus sp. 23, but the absence of a morphological description for these species (Mendoza-Palmero et al., 2015) limits conclusions at the present time. No sequences of either Demidospermus specimens from Brazil or monogenean parasites from loricariid fishes have been performed until now. The present study therefore provides, for the first time, data regarding the molecular characterization of Demidospermus species parasitizing loricariid fishes, supporting future investigations and phylogenetic studies.

Demidospermus spirophallus n. sp., D. prolixus $\mathrm{n}$. sp. and $D$. anus clustered together within the most diverse clade, the Neotropical region (clade C, see Mendoza-Palmero et al., 2015), and were closely related to the monogeneans previously described in the Ancylodiscoidinae subfamily. These three species of Demidospermus from Brazilian loricariids did not group together with other Demidospermus species parasites of pimelodids from Peru (Demidospermus sp. 23, Demidospermus sp. 11 and D. mortentahleri), exhibiting a distant relationship, as described previously by Mendoza-Palmero et al. (2015), reinforcing the fact that this genus is not natural. Based on the results of the morphological and molecular data presented in this study, we suggest that, in fact, lineages of dactylogyrids from loricariids belong to the Demidospermus genus, and an erection of two new genera should be proposed to accommodate parasite species of pimelodids from Peru (one to accommodate the species Demidospermus sp. 23 and Demidospermus sp. 11, and another for D. mortentahleri). However, future morphological and phylogenetic analyses with the inclusion of new sequences of dactylogyrids identified as belonging to the Demidospermus genus from other siluriform fish may clarify the host associations, and confirm whether this dactylogyrid possesses specificity for parasitizing loricariid fishes or if, in fact, they can be distributed among siluriform fishes in general.

\section{Acknowledgements}

We are most grateful to Edmir Daniel Carvalho (in memoriam), professor and researcher at the Universidade Estadual Paulista, Botucatu Campus, São Paulo, Brazil, who dedicated his life to the study of ecology and environmental impacts on rivers and reservoirs caused by anthropic actions, and actively participated in the development of this project. We would like to thank Sandro Geraldo de Castro Britto and Diogo Freitas Souza for logistical support in the collection of hosts; 
Aline Gouveia de Souza Lins for help in the analysis of parasites; and Cláudio Henrique Zawadzki, Walter Antonio Pereira Boeger, Rodney Kozlowiski de Azevedo and Vanessa Doro Abdallah Kozlowiski for taxonomic suggestions. We are also most grateful to Simone Chinicz Cohen and Anna Kohn (Oswaldo Cruz Foundation - FIOCRUZ) for allowing us to examine some specimens of Demidospermus in their care.

\section{Financial support}

The authors would like to thank CAPES (Coordination for the Improvement of Higher Education Personnel) and FAPESP (São Paulo Research Foundation) (L.F. - Process: 2012/07850-7) for financial and scientific support, and the post-graduate scholarships granted to M.I.M. (grant number AUX-PE-PNPD 3005/2010); and the Young Researcher Program PROPE-UNESP 02/2016 and New Doctor Program PROPE-UNESP 03/2016 for the scholarships granted to M.I.M. and L.F., respectively. R.J.S. is supported by CNPq (307808/2014-9) and CNPq-PROTAX (440496/2015-2)/FAPESP 2016/50377-1. We would also like to thank FUNEP (Teaching and Extension Research Support Foundation) (Process: 1.01852/2011), Duke Energy and CELAN (Central Elétrica Anhanguera) for financial and logistical support.

\section{Conflict of interest}

None.

\section{Ethical standards}

Specimens of L. prolixa were collected under Permanent License for the Collection of Zoological Material - SISBio 13794-1.

\section{References}

ANEEL (Agência Nacional de Energia Elétrica) (2008) Atlas de Energia Elétrica do Brasil. Brasília, ANEEL.

Armbruster, J.W. (2004) Phylogenetic relationships of the suckermouth armoured catfishes (Loricariidae) with emphasis on the Hypostominae and the Ancistrinae. Zoological Journal of the Linnean Society 141, 1-80.

Azevedo, R.K., Abdallah, V.D. \& Luque, J.L. (2010) Acanthocephala, Annelida, Arthropoda, Myxozoa, Nematoda and Platyhelminthes parasites of fishes from the Guandu river, Rio de Janeiro, Brazil. Check List 6, 659-667.

Braga, M.P., Araújo, S.B.L. \& Boeger, W.A (2014) Patterns of interaction between Neotropical freshwater fishes and their gill Monogenoidea (Platyhelminthes). Parasitology Research 113, 481-490.

Burguess, W.E. (1989) An atlas of freshwater and marine catfishes - a preliminary survey of the Siluriformes. 784 pp. Neptune City, New Jersey, T.F.H. Publications.

Cepeda, B.P. \& Luque, J.L. (2010) Three new species of Demidospermus (Monogenea: Dactylogyridae) parasitic on Brachyplatystoma filamentosum (Siluriformes: Pimelodidae) from the Araguaia River, Brazil. Journal of Parasitology 96, 869-973.
Chiachio, M.C., Oliveira, C. \& Montoya-Burgos, J.I. (2008) Molecular systematic and historical biogeography of the armored Neotropical catfishes Hypoptopomatimae and Neoplecostominae (Siluriformes: Loricariidae). Molecular Phylogenetics and Evolution 49, 606-617.

Chisholm, L.A., Morgan, J.A., Adlard, R.D. \& Whittington, I.D. (2001) Phylogenetic analysis of the Monocotylidae (Monogenea) inferred from 28S rDNA sequences. International Journal for Parasitology 31, 1537-1547.

Cohen, S.C. \& Kohn, A. (2008) New data on species of Demidospermus (Dactylogyridae: Monogenea) parasitizing fishes from the reservoir of the Itaipu Hydroelectric Power Station, Paraná State, Brazil, with new synonymies. Revista Brasileira de Parasitolologia Veterinária 17, 167-170.

Cohen, S.C., Justo, M.C.N. \& Kohn, A. (2013) South American Monogenoidea parasites of fishes, amphibians and reptiles. 1st edn. 663 pp. Rio de Janeiro, Oficina de Livros.

Drummond, A.J., Suchard, M.A., Xie, D. \& Rambaut, A. (2012) Bayesian phylogenetics with BEAUti and the BEAST 1.7 Molecular Biology and Evolution 29, 19691973.

Eschmeyer, W.N., Fricke, R. \& van der Laan, R. (Eds) (2016) Catalog of fishes: genera, species, references. Available at http://researcharchive.calacademy.org/ research/ichthyology/catalog/fishcatmain.asp (accessed November 2016).

Fehlauer-Ale, K.H. \& Littlewood, D.T.J. (2011) Molecular phylogeny of Potamotrygonotyle (Monogenea, Monocotylidae) challenges the validity of some of its species. Zoologica Scripta 40, 638-658.

Ferrari-Hoeinghaus, A.P., Bellay, S., Takemoto, R.M. \& Pavanelli, G.C. (2010) A new species of Demidospermus Suriano, 1983 (Monogenea, Dactylogyridae) parasitic on Loricariichthys platymetopon Isbrücker et Nijssen (Loricariidae, Siluriformes) from the Upper Paraná River floodplain, Brazil. Acta Parasitologica 55, 16-19.

França, J.G., Isaac, A., Pavanelli, G.C. \& Takemoto, R.M. (2003) Dactylogyridae (Monogenea) from the gills of Iheringichthys labrosus (Osteichthyes: Pimelodidae) from the upper Paraná River floodplain, Brazil, with the proposal of Pseudovancleaveus n. g. Systematic Parasitology 54, 25-31.

Froese, R. \& Pauly, D. (Eds) (2016) FishBase (www database). World wide web electronic publication. Available at http://www.fishbase.org (accessed June 2016).

Gilmore, S.R., Cone, D.K., Lowe, G., King, S.K., Jones, S.R.M. \& Abbott, C.L. (2012) Molecular phylogeny of Gyrodactylus (Monogenea) parasitizing fishes in freshwater, estuarine, and marine habitats in Canada. Canadian Journal of Zoology 90, 776-786.

Gutiérrez, P.A. \& Suriano, D.M. (1992) Ancyrocephalids of the genus Demidospermus Suriano, 1983 (Monogenea) parasites from siluriform fishes in Argentina, with descriptions of three new species. Acta Parasitologica 37, 169-172.

Hahn, C., Bakke, T.A., Bachmann, L., Weiss, S. \& Harris, P.D. (2011) Morphometric and molecular characterization of Gyrodactylus teuchis Lautraite, Blanc, Thiery, Daniel \& Vigneulle, 1999 (Monogenea: Gyrodactylidae) from an Austrian brown trout population. Parasitology International 60, 480-487. 
Kearse, M., Moir, R., Wilson, A., Stones-Havas, S. Cheung, M., Sturrock, S., Buxton, S., Cooper, A., Markowitz, S., Duran, C., Thierer, T., Ashton, B., Mentjies, P. \& Drummond, A. (2012) Geneious Basic: an integrated and extendable desktop software platform for the organization and analysis of sequence data. Bioinformatics 28, 1647-1649.

Kritsky, D.C. \& Gutiérrez, P.A. (1998) Neotropical Monogenoidea. 34. Species of Demidospermus (Dactylogyridae, Ancyrocephalinae) from the gills of pimelodids (Teleostei, Siluriformes) in Argentina. Journal of the Helminthological Society of Washington 65, 147-159.

Kritsky, D.C. \& Thatcher, V.E. (1976) New monogenetic trematodes from freshwater fishes of western Colombia with the proposal of Anacanthoroides gen. n. (Dactylogyridae). Proceedings of the Biological Society of Washington 43, 129-134.

Kristsky, D.C, Thatcher, V.E. \& Boeger, W.A. (1986) Neotropical Monogenea. 8. Revision of Urocleidoides (Dactylogyridae, Ancyrocephalinae). Proceedings of the Helminthological Society of Washington 53, 1-37.

Kritsky, D.C., Thatcher, V.E. \& Boeger, W.A. (1987) Neotropical Monogenea. 10. Omothecium, new genus (Dactylogyridae: Ancyrocephalinae) and two new species from the Piranambu, Pinirampus pirinampu (Spix), (Siluriformes), in Brazil. Proceedings of the Biological Society of Washington 100, 8-12.

Littlewood, D.T.J., Curini-Galletti, M. \& Herniou, E.A. (2000) The interrelationships of Proseriata (Platyhelminthes: Seriata) tested with molecules and morphology. Molecular Phylogenetics and Evolution 16, 449-466.

Lockyer, A.E., Olson, P.D. \& Littlewood, D.T.J. (2003) Utility of complete large and small subunit rRNA genes in resolving the phylogeny of the Neodermata (Platyhelminthes): implications and a review of the cercomer theory. Biological Journal of the Linnean Society 78, 155-171.

Marcotegui, P.S. \& Martorelli, S.R. (2011) A new species of Demidospermus (Platyhelminthes, Monogenea, Ancyrocephalidae) from the catfish Parapimelodus valenciennis in Samborombón Bay, Argentina. Acta Parasitologica 56, 116-121.

Mendoza-Franco, E.F. \& Scholz, T. (2009) New dactylogyrids (Monogenea) parasitizing the gills of catfishes (Siluriformes) from the Amazon River Basin in Peru. Journal of Parasitology 95, 865-870.

Mendoza-Palmero, C.A. \& Scholz, T. (2011) New species of Demidospermus (Monogenea: Dactylogyridae) of pimelodid catfish (Siluriformes) from Peruvian Amazonia and the reassignment of Urocleidoides lebedevi Kritsky and Thatcher, 1976. Journal of Parasitology 97, 586-592.

Mendoza-Palmero, C.A., Scholz, T., Mendoza-Franco, E. F. \& Kuchta, R. (2012) New species and geographical records of Dactylogyrids (Monogenea) of catfish (Siluriformes) from the Peruvian Amazonia. Journal of Parasitology 98, 484-497.

Mendoza-Palmero, C.A., Blasco-Costa, I. \& Scholz, T. (2015) Molecular phylogeny of Neotropical monogeneans (Platyhelminthes: Monogenea) from catfishes (Siluriformes). Parasite $\mathcal{E}$ Vectors 8, 164.
Mizelle, J.D. (1936) New species of trematodes from the gills of Illinois fishes. The American Midland Naturalist Journal 17, 785-806.

Monteiro, C.M., Kritsky, D.C. \& Brasil-Sato, M.C. (2010) Neotropical Monogenoidea 55. Dactylogtyrids parasitizing the pintado-amarelo Pimelodus maculatus Lacépède (Actinopterygii: Pimelodidae) from the Rio São Francisco, Brazil. Systematic Parasitology 76, 179-190.

Nelson, J.S. (2006) Fishes of the world. 4th edn. 595 pp. New York, John Wiley \& Sons.

Plaisance, L., Littlewood, D.T.J., Olson, P.D. \& Morand, S. (2005) Molecular phylogeny of gill monogeneans (Platyhelminthes, Monogenea, Dactylogyridae) and colonization of Indo-West Pacific butterflyfish hosts (Perciformes, Chaetodontidae). Zoologica Scripta 34, 425-436.

Posada, D. (2008) jModelTest: phylogenetic model averaging. Molecular Biology and Evolution 25, 1253-1256.

Poulin, R. (2002) The evolution of monogenean diversity. International Journal for Parasitology 32, 245-254.

Rambaut, A. (2009) Molecular evolution, phylogenetics and epidemiology: Fig-Tree. Available at http//tree. bio.ed.ac.uk/software/figtree/ (accessed 10 November 2015).

Reis, R.E., Weber, C. \& Malabarba, L.R. (1990) Review of the genus Hypostomus Lacépède, 1803 from southern Brazil, with descriptions of three new species (Pisces, Siluriformes, Loricariidae). Revue Suisse de Zoologie 97, 729-766.

Roxo, F.F., Albert, J.S., Silva, G.S.C., Zawadzki, C.H., Foresti, F. \& Oliveira, C. (2014) Molecular phylogeny and biogeographic history of the armored Neotropical catfish Subfamilies Hypoptopomatinae, Neoplecostominae and Otothyrinae (Siluriformes: Loricariidae). PLoS One 9, e105564.

Sarabeev, V. \& Desdevises, Y. (2014) Phylogeny of the Atlantic and Pacific species of Ligophorus (Monogenea: Dactylogyridae): morphology vs. molecules. Parasitology International 63, 9-20.

Simková, A., Matejusová, I. \& Cunningham, C.O. (2006) A molecular phylogeny of the Dactylogyridae sensu Kritsky \& Boeger (1989) (Monogenea) based on the D1-D3 domains of the large subunit rDNA. Parasitology 133, 43-53.

Sullivan, J.P., Lundberg, J.G. \& Hardman, M.A. (2006) A phylogenetic analysis of the major groups of catfishes (Teleostei: Siluriformes) using rag1 and rag2 nuclear gene sequences. Molecular Phylogenetics and Evolution 41, 636-662.

Suriano, D.M. (1983) Demidospermus anus gen. nov. sp. nov. (Monogenea: Ancyrocephalinae) parásita branquial de Loricaria (L.) anus Valenciennes, 1840 (Pisces: Loricariidae) de la laguna de Chascomús, provincia de Buenos Aires, República Argentina. Neotropica 29, 111-119.

Suriano, D.M. \& Incorvaia, S. (1995) Ancyrocephalid (Monogenea) parasites from siluriform fishes from the Paranean-Platean ichthyogeographical province in Argentina. Acta Parasitologica 40, 113-124.

Tavernari, F.C., Takemoto, R.M., Lacerda, A.C.F. \& Pavanelli, G.C. (2010) A new species of Demidospermus Suriano, 1983 (Monogenea) parasite of gills of 
Auchenipterus osteomystax (Auchenipteridae), from the upper Paraná river floodplain, Brazil. Acta Scientiarum. Biological Sciences 32, 79-81.

Thatcher, V.E. (2006) Aquatic biodiversity in Latin America: Amazon fish parasites. 2nd edn. 508 pp. Bulgaria, Pensoft.

Weber, C. (2003) Subfamily Hypostominae (armored catfishes). pp. 351-372 in Reis, R.E., Kullander, S.O. \& Ferraris, C.J. (Eds) Check list of the freshwater fishes of South and Central America. Porto Alegre, Edipurcs.

Wu, X.Y., Zhu, X.Q., Xie, M.Q. \& Li, A.X. (2006) The radiation of Haliotrema (Monogenea: Dactylogyridae: Ancyrocephalinae): molecular evidence and explanation inferred from LSU rDNA sequences. Parasitology 132, 659-668.

Wu, X.Y., Zhu, X.Q., Xie, M.Q. \& Li, A.X. (2007) The evaluation for generic-level monophyly of Ancyrocephalinae (Monogenea, Dactylogyridae) using ribosomal DNA sequence data. Molecular Phylogenetics and Evolution 44, 530-544.

Wu, X.Y., Zhu, X.Q., Xie, M.Q., Wang, J.Q. \& Li, A.X. (2008) The radiation of Thaparocleidus (Monogenoidea: Dactylogyridae: Ancylodiscoidinae): phylogenetic analyses and taxonomic implications inferred from ribosomal DNA sequences. Parasitology Research 102, 283-288. 